\title{
Biomonitoring of Fresh Water of Loktak Lake, India
}

By

\author{
N.K. Sharat Singh ${ }^{1}$, M. Sudarshan ${ }^{2}$, A. Chakraborty ${ }^{2}$, Ch. Bino Devi ${ }^{3}$, \\ Th. Brojendro Singh ${ }^{3}$, N. Rajmuhon Singh ${ }^{4 *}$
}

\begin{abstract}
The fresh water Mollusca (Scientific name; Pila globosa) was collected from nine different stations of Loktak lake to investigate the elemental profile in the tissue of it as it can be used as biomonitor of the pollution of water. As the Gastropoda family is a feeder filter, it is very useful to examine the trace elements as well as toxic elements in the environment where it survives. The elements detected in the samples are $\mathrm{Mg}, \mathrm{Al}, \mathrm{P}, \mathrm{S}, \mathrm{Cl}, \mathrm{K}, \mathrm{Ca}, \mathrm{Mn}$, $\mathrm{Fe}, \mathrm{Cu}, \mathrm{Zn}, \mathrm{Se}, \mathrm{Br}, \mathrm{Rb}, \mathrm{Sr}$ and the elemental concentrations were compared with FAO limits to check their toxic levels. The elements detected so far are the time integral of their concentration so, that are several orders of magnitude above ambient water concentrations. The analysis of the elements was done with the help of energy dispersive $\mathrm{X}$-ray fluorescence (EDXRF) for its quick and multi-elemental detection capability.
\end{abstract}

Keywords: Pila globosa, Biomonitoring, Loktak lake, Trace elements, EDXRF

\section{Introduction}

Biomonitor means the species that accumulate trace elements in their tissue and therefore can be used to monitor the availability of these elements in the particular environment where they survive. The ultimate aim in ecotoxicology is to predict the effects and to diagnose the causes of ecological/biological effects that resulted from exposure to chemicals (heavy metals) and environmental stresses [1]. The pollution levels of the aquatic environment by heavy metals can be estimated by analysing water, sediments and marine organisms. Chemical analysis of the water does not provide information on the bioavailability of metals present in the environment [2]. Again, while it is possible to utilize direct chemical analyses of water and sediment which are usually very sensitive and accurate, monitoring systems which employ direct analysis do not necessarily reflect the true ecological state, for several reasons [3]. First, the number and

Department of Physics, Manipur University, Canchipur, Imphal-795 003

${ }^{2}$ UGC-DAE Consortium for Scientific Research, Kolkata Centre, Kolkata-700 098

${ }^{3}$ Department of Chemistry, Oriental College, Imphal-795001

${ }^{4}$ Department of Chemistry, Manipur University, Canchipur, Imphal-795 003

${ }^{*}$ Corresponding author 
range of pollutants known to be discharged to the environment far exceeds the capability of available chemical tests, not to mention unknown pollutants. Second, pollutants may act synergistically, which limits the value of direct measurements dramatically. Finally, the true threat to the environment and its inhabitants also depends on the biological availability of suspected agents, which cannot be accounted for by chemical means. Moreover, biomonitors, exclusively provide time-integrated measures of the bioavailable levels of substance [4]. One of the criteria when an organism is proposed as a biomonitoring agent is a simple correlation between pollutant levels present in the organism and those in its environment [5]. Molluscas are filter-feeders and thus obtain heavy metals not only from food and water but also from ingestion of inorganic particulate materials. Gastropoda mollusks [6-8] were employed as bio-indicator to determine the effect of marine pollution. These organisms were considered as appropriate bio-indicators since they are available all year long and easily collected. In addition to it, they are found in all types of surface water systems [9].

Loktak lake is considered as the lifeline of Manipur, due to its importance in the socioeconomic and cultural life of the people. It is the largest natural fresh water lake in the north-eastern region of India with an area of $236.21 \mathrm{~km}^{2}$ and plays an important role in the ecological and economic security of the region. The sewage and other waste products from industries in the Imphal town are drained into Nambul river and help directly to dump into the Loktak lake. The quality of water of this river is badly affected while it enters the city as the sewage, waste products from industries are dumped into it. Population of 0.28 million living within Nambul river catchments generates 31,207 cubic metre of sewage daily. With rapid urbanization, industrialization and increasing population of the city the river gets polluted day by day leading to the increase of pollution levels of Loktak lake. The pollution of the lake is also being increased day by day due to the use of excessive amount of fertilizers, pesticides, insecticides and fungicides by the farmers, cultivators and people around the lake. Trace metals and their compounds are the non-degradable pollutants and they cannot be destroyed. Hence, the pollution of the lake is monitored with the help of bio-indicator viz. Pila globosa, Family: Gastropoda which is also used as a food item. The EDXRF technique was used for trace elemental analysis of the bioindicator samples for its quick, powerful, reliable and multielemental detection capability. Here, the term 'trace metal' suggests occurrence at low (trace) concentrations (sometimes defined as $0.01 \%$ dry weight) in the environment, in both physical and biotic components, yet all of these metals do occur in raised concentrations in ores and some spectacularly so in organisms, as will be demonstrated. Moreover, the comparative study of the elements present in Pila globosa with that of FAO limits, a valuable conclusion can be made as the deficit or excess of trace elements may lead to metabolic disorder and health hazard.

\section{Experimental}

\subsection{Sample Collection}

Fig. 1 shows the map of Loktak lake (not scaled) and the central geographical position of the lake in terms of latitude and longitude is $24^{0} 32^{\prime}$ and $93^{\circ} 49^{\prime}$ respectively with an 
altitude $2516 \mathrm{ft}$ above sea level. The specimens having approximate same size are collected from nine different sites around the lake and coded it as Moll 1, Moll 2 and so on. The muscular part excluding the intestinal portion which is inside the hard shell of Pila globosa was taken out and washed with distilled water several times to avoid any soil and foreign contamination.

\subsection{Sample treatment}

The tissue samples were dried in an oven at $65^{\circ} \mathrm{C}$ for $24 \mathrm{~h}$ and grounded into powder. Grinding of the samples is necessary to have homogeneity in three dimensions. $150 \mathrm{mg}$ of the sample powder were pelletised into a thin pellet of uniform thickness having 13 $\mathrm{mm}$ in diameter under a pressure of $130 \mathrm{~kg} / \mathrm{cm}^{2}$ for two minutes.

\subsection{Instrumental}

The elemental analysis of the samples was carried out using a Jordan Valley EX-3600 Energy Dispersive X-ray Fluorescence (EDXRF) spectrometer, which consists of an oilcooled Rh anode X-ray tube (maximum voltage $50 \mathrm{kV}$ ). The measurements were carried out in vacuum using different filters (between the source and sample for optimum detection of elements. The anode voltage of the $\mathrm{X}$-ray tube was kept at $6 \mathrm{kV}, 14 \mathrm{kV}$ and $23 \mathrm{kV}$ with no filter, Ti and Fe filter respectively. All measurements were carried out for 200 s. The X-rays were detected using a liquid-nitrogen-cooled $12.5 \mathrm{~mm}^{2} \mathrm{Si}$ (Li) semiconductor detector (resolution $150 \mathrm{eV}$ at $5.9 \mathrm{keV}$ ) which was seen in the monitor fitted with the spectrometer. The spectra were analysed by the software called ExWIN integrated with the system [10]. The NIST bovine liver standard (SRM 1577c), apple leaf standard (SRM 1515), blood (IAEA A-13) were used as external standard reference materials.

\section{Results and discussion}

The EDXRF analysis was done for three replicates in each sample and altogether, fifteen elements viz. $\mathrm{Mg}, \mathrm{Al}, \mathrm{P}, \mathrm{S}, \mathrm{Cl}, \mathrm{K}, \mathrm{Ca}, \mathrm{Mn}, \mathrm{Fe}, \mathrm{Cu}, \mathrm{Zn}, \mathrm{Se}, \mathrm{Br}, \mathrm{Rb}$ and $\mathrm{Sr}$ were analysed. The mean concentrations with the standard deviations of the detected elements are shown in Table 1 and 2. The great variations occurring within one population, expressed in high standard deviations, are not unexpected reflecting the complex relationship between environmental concentrations and bioaccumulation [11]. As evident from Table 1 and 2, concentration of calcium was found to be highest in the range 12021.4 to $49420.6 \mathrm{ppm}$ and that of the selenium as least concentration with the range 0.2 to 3.2 ppm. Moreover, highly toxic elements like $\mathrm{Cd}$, As and $\mathrm{Pb}$ which was reported by earlier worker [12], could not be observed signifying that the water of the lake is not polluted with these elements. However, the elements detected as shown in the two tables, enable us to make conclusions about the idea of bioavailable element and pollution sources in the respective aquatic environment. It is appropriate to mention that the concentration of the dissolved metals in water gives the total, not bioavailable metal concentrations. 
The comparison of concentrations of some elements viz. $\mathrm{Cu}, \mathrm{Zn}$ and Se with that of the Food and Agricultural Organisation (FAO) of the United Nations are shown in Table 3 [13]. The concentrations of $\mathrm{Cu}$ and $\mathrm{Zn}$ are a bit less and that of $\mathrm{Se}$ is a bit higher as compare to FAO limits. Again, the essential elements take different roles in the proper functioning of life process. A deficit or excess in the supply of the elements in our food item will lead to metabolic disorder. Some of the daily intake requirements of elements are given as follows: $\mathrm{P}-700 \mathrm{mg}, \mathrm{Cl}-750 \mathrm{mg}, \mathrm{Ca}-1000$ to $1200 \mathrm{mg}, \mathrm{Cr}-0.05$ to $0.2 \mathrm{mg}$, $\mathrm{Cu}-1.5$ to $3 \mathrm{mg}$ [14]. The richness in $\mathrm{Ca}$ is significant for using it in $\mathrm{Ca}$ deficient persons. Each element is used for the smooth functioning of our body except for $\mathrm{Rb}, \mathrm{Sr}$ and $\mathrm{Al}$ whose functions are not clear. The Se containing in the samples is remarkable as this element has anti-oxidant property so that it can be used for cancer treatment.

The coefficient of correlation among the elements in molluca tissue samples is shown in Table 4 and it was found to be highest in between $\mathrm{Mn}$ and $\mathrm{Br}$ followed by $\mathrm{Mn}$ and $\mathrm{Cl}$ with the coefficients 0.941 and 0.844 respectively. This signifies that when the Mn concentration is increased, the concentrations of $\mathrm{Br}$ and $\mathrm{Cl}$ are also increased showing the strong correlation between this two elements whose coefficient 0.797 as evident from the table. The highest negative coefficient of 0.715 is found between $\mathrm{Ca}$ and $\mathrm{P}$ suggesting for not formation of $\mathrm{CaPO}_{4}$ or other calcium and phosphorus containing compounds in the tissue of Pila globosa. The factor analysis of the different elements was done with the help of principal component analysis extraction method. Factor analysis aims at obtaining the prominent interpretable factors hidden in the data set that explain as much of the total variability as possible. A total of four components were extracted from the analysis. The component score coefficient matrix is shown in Table 5. As evident from the table, it is observed that four components can be extracted out of which $\mathrm{P}, \mathrm{Cl}, \mathrm{Mn}, \mathrm{Br}$ take main role for loading in the first component as compared to remaining components and similarly, $\mathrm{Al}, \mathrm{Fe}, \mathrm{Se}, \mathrm{Rb}$ in the second component; $\mathrm{Mg}, \mathrm{K}$, $\mathrm{Ca}, \mathrm{Sr}$ in the third component; S, Cu, $\mathrm{Zn}$ in the fourth component respectively.

Different metals dissolved in water may be accumulated by direct adsorption onto the body surface of mollusca, while particulate metals can be accumulated by organisms following the ingestion and digestion of food [15] as aquatic molluscs possess very diverse strategies in the handling and storage of accumulated metals. In addition to it, environmental and biological factors including dissolved metal interactions have been considered for their influence on trace metal uptake and bioaccumulation [16]. So, the food habit of Pila globosa as well as concentration of the various dissolved metals of the water environment where they survive is also important to know. The relatively insoluble compounds in the soil containing essential iron, manganese, copper and zinc are solubilized by chelating agents as the citrate anion. For manganese the microorganism is bacteria to dissolve the compounds of it in the soil and rocks by the anaerobic action. In most soils, several of these effective chelating agents are produced naturally from soil organic matter by soil microorganisms [17]. Thus the dissolved metals in water must have taken some roles in the bioavailability of the said metals. 


\section{Conclusion}

The elements present in the muscular tissue of Pila globosa have been observed with their concentrations by using EDXRF technique. The elements detected in the samples are $\mathrm{Mg}, \mathrm{Al}, \mathrm{P}, \mathrm{S}, \mathrm{Cl}, \mathrm{K}, \mathrm{Ca}, \mathrm{Mn}, \mathrm{Fe}, \mathrm{Cu}, \mathrm{Zn}, \mathrm{Se}, \mathrm{Br}, \mathrm{Rb}$, Sr. Some elements were detected with high standard deviations while taking the mean from three replicates for the samples each leading to the fact that there is some complex relationship between environmental concentrations and bioaccumulation. The highest positive and negative coefficient of correlations were observed in between $\mathrm{Mn}$ and $\mathrm{Br}$; $\mathrm{Ca}$ and $\mathrm{P}$ respectively among the elements. From the comparative study of concentrations of some elements with $\mathrm{FAO}$ limits and non detection of toxic elements like $\mathrm{As}, \mathrm{Cd}, \mathrm{Hg}$, and $\mathrm{Pb}$, it is concluded that the water of the lake is fresh in terms of trace elemental pollutants. Lastly, our observation shows that Pila globosa can also be used for biomonitoring of polluted environment.

\section{Acknowledgements}

The authors are thankful to the UGC-DAE Consortium for Scientific Research, Kolkata Centre for extending the facility for the analysis work and would like to acknowledge the technical assistance of Mr. Ajay Rathore for carrying out this work. Further, the authors would like to thank Ministry of Environment and Forests, GoI, for the financial assistance in the research work.

\section{References}

Widdows J, Donkin P. Mussels and environmental contaminants: bioaccumulation and physiological aspects. In: Gosling E, editor. The mussel Mytilus: ecology physiology, genetics and culture. Amsterdam: Elsevier, 1992. p. 399.

Morillo, J., Usero, J., Gracia, I. Biomonitoring of trace metals in a mine-polluted estuarine system (Spain). Chemosphere 58, (2005), 1421-1430.

Vladimir Bresler, Avigdor Abelson, Lev Fishelson, Tamar Feldstein, Michael Rosenfeld, Ofer Mokady. Marine molluscs in environmental monitoring. Helgol Mar Res 57 (2003) 157165

M. Camusso, R. Balestrini, F. Muriano, M. Mariani. Use of freshwater mussel Dreissena polymorpha to assess trace metalpollution in the lower river Po (Italy). Chemosphere, 29 (4), (1994), 729-745

Rainbow PS. Trace metal accumulation in marine invertebrates: marine biology or marine chemistry? J Mar Biol Assoc UK 77 (1997), 195-210.

Campanella, L., Conti, M. E., Cubadda, F., \& Sucapane,C. (2001). Trace metals in seagrass and mollusks from an uncontaminated area in the Mediterranean. Environmental Pollution, 111, $117-126$.

Türkmen, M., Türkmen, A., Akyurt, I., \& Tepe, Y. (2005). Limpet, Patella caerulea Linnaeus, 1758 and barnacle, Balanus sp., as biomonitors of trace metal availabilities in Iskenderun Bay, Northern East Mediterranean Sea. Bulletin of Environmental Contamination and Toxicology, 74, 301-307.

T. A. Yüzerero glu · G. Gök · H. Y. Ço gun · Ö. Firat · Sabahattin Aslanyavrusu · Onur Maruldalı · F. Kargin. Heavy metals in Patella caerulea (Mollusca, Gastropoda) in polluted 
and non-polluted areas from the Iskenderun Gulf (Mediterranean Turkey) Environ Monit Assess (2010) 167:257-264

J. J. Elder, J. J. Collins. Fresh water molluscs as indicators of bioavailability and toxicity of metals in surface water systems Rev. Environ. Contam. Toxicol, 122 (1991) 37-79

Ch. Bino Devi, N.K. Sharat Singh, N. Rajmuhon Singh, N. Rajendro Singh,

M. Sudarshan, A. Chakraborty, S.S. Ram (2011), International Journal of Applied Biology and Pharmaceutical Technology 2(1) $198-203$.

A. Wagner, J. Boman (2004) Biomonitoring of trace elements in Vietnamese freshwater mussels spectrochimica Acta B 59(8) 1125-1132

P. S. Rainbow (2006) biomonitoring of trace metals in estuarine and marine environments Australasian journal of ecotoxicology 12, 107-122

Carlifornia Environmental Protection Agency, State Water Resources Control Board, Appendix V: Median International Standards, homepage://www.swcb.ca.gov, accessed: September 2002.

S. Raychaudhuri, M. Mishra, S Salodkar, M. Sudarshan, A. R. Thakur (2008). Traditional aquaculture practice at east Calcutta Wetland: The safety assessment.American Journal of environmental Sciences,4(2): 173-177.

Wang, W.-X., \& Fisher, N. S. (1999). Delineating metal accumulation pathways for marine invertebrates. The Science of the Total Environment, 237/238, 459-472.

Amiard-Triquet, C., \& Amiard, J. C. (1998). Influence of ecological factors on accumulation of metal mixture. In W. J. Langston \& M. J. Bebianno (Eds.), Metal metabolism in aquatic environments (pp. 351-386). London: Chapman and Hall.

Mack Drake (1964). Soil Chemistry and Plant Nutrition. In Firman Bear (Eds.), Chemistry of Soil (pp. 432). Oxford \& IBH publishing Co. 


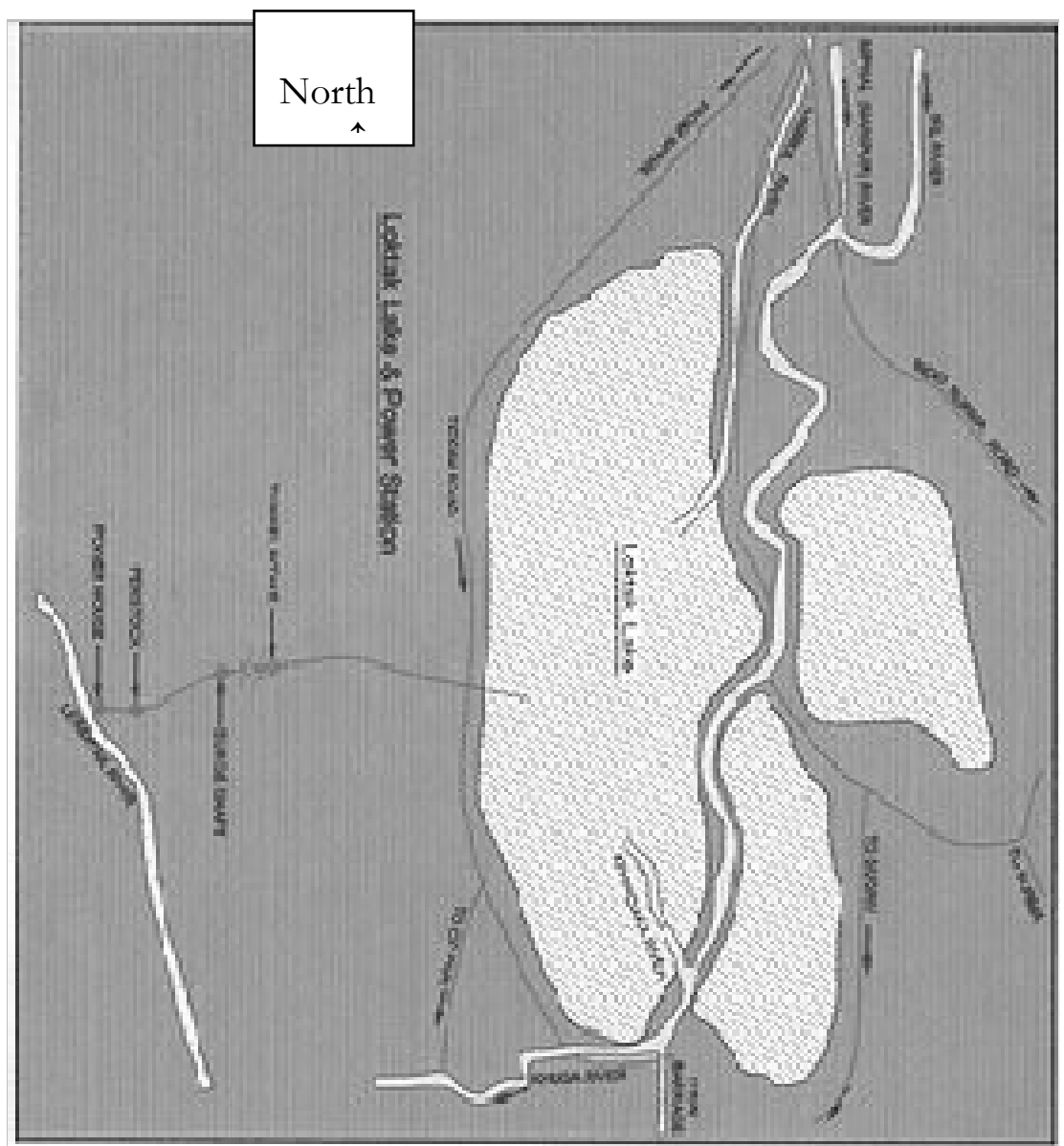

Fig. 1 Map of Loktak lake 
Table 1. Concentration (ppm) of the major elements in Pila globosa for three replicates in each sample

\begin{tabular}{|c|c|c|c|c|c|c|c|}
\hline $\begin{array}{l}\text { Sample } \\
\text { Id }\end{array}$ & $\mathrm{Mg}$ & $\mathrm{P}$ & $\mathrm{S}$ & $\mathrm{K}$ & \multicolumn{2}{|l|}{$\mathrm{Ca}$} & $\mathrm{Fe}$ \\
\hline Moll-1 & $3547.0 \pm 415.1$ & \multicolumn{2}{|c|}{$4869.3 \pm 513.44874 .8 \pm 500.3$} & $5811.9 \pm 397.5$ & $39143 \pm 3261.2$ & \multicolumn{2}{|c|}{$1376.9 \pm 154.2$} \\
\hline Moll-2 & $4139.6 \pm 149.9$ & $5639.7 \pm 372.4$ & $5757 \pm 103.86$ & $6406.1 \pm 254.3$ & $43878.5 \pm 3368.9$ & & \\
\hline Moll-3 & $2496.7 \pm 249.7$ & $7494.5 \pm 658.4$ & $6631.4 \pm 564.4$ & $4857.3 \pm 336.1$ & 2595 & 6.9 & $202.7 \pm 9.4$ \\
\hline Moll-4 & $3955.8 \pm 294.8$ & $5077.7 \pm 370.8$ & $4886.6 \pm 493.8$ & $5993.8 \pm 418.2$ & 3585 & & $2602.7 \pm 287.6$ \\
\hline Moll-5 & $3818.1 \pm 284.9$ & $9839.3 \pm 286.7$ & $5882.7 \pm 264.4$ & $6725.9 \pm 205.5$ & 1202 & & $2778.5 \pm 145.6$ \\
\hline Moll-6 & $1881.1 \pm 221.3$ & $6475.2 \pm 688.3$ & $5966.1 \pm 568.6$ & $5241.8 \pm 440.3$ & 1605 & 6.6 & $407.2 \pm 8.5$ \\
\hline Moll-7 & $3554.6 \pm 254.3$ & $4838.5 \pm 223.3$ & $4688.7 \pm 290.5$ & $4695.4 \pm 373.2$ & 4942 & & $181.2 \pm 8.8$ \\
\hline Moll-8 & $3631.2 \pm 243.2$ & $6389.0 \pm 409.8$ & $6067.4 \pm 546.3$ & $5790.2 \pm 390.6$ & 3513 & & $1072.7 \pm 127.8$ \\
\hline Moll-9 & $3601.8 \pm 259.0$ & $6366.5 \pm 589.6$ & $5806.9 \pm 322.1$ & $5760.4 \pm 546.5$ & 4278 & & $1570.4 \pm 97.2$ \\
\hline
\end{tabular}

Table 2. Concentration (ppm) of the minor and trace elements in Pila globosa for three replicates in each sample.

\begin{tabular}{lllllllllll}
\hline $\begin{array}{l}\text { Sample } \\
\text { ID }\end{array}$ & $\mathrm{Al}$ & $\mathrm{Cl}$ & $\mathrm{Mn}$ & $\mathrm{Cu}$ & $\mathrm{Zn}$ & $\mathrm{Se}$ & $\mathrm{Br}$ & $\mathrm{Rb}$ & $\mathrm{Sr}$ \\
\hline Moll-1 & $1474.3 \pm 231.5$ & $928.2 \pm 79.9$ & $148.6 \pm 13.9$ & $7.2 \pm 0.1$ & $155.9 \pm 3.5$ & $3.2 \pm 0.5$ & $6.7 \pm 0.3$ & $13.2 \pm 3.0$ & $69.5 \pm 4.2$ \\
Moll-2 & $301.5 \pm 115.1$ & $1043.2 \pm 55.3$ & $33.7 \pm 1.3$ & $23.6 \pm 1.0$ & $159.0 \pm 3.6$ & $2.3 \pm 1.8$ & $10.0 \pm 0.6$ & $7.6 \pm 1.4$ & $69.7 \pm 5.7$ \\
Moll-3 & $133.1 \pm 12.8$ & $838.5 \pm 76.3$ & $57.1 \pm 10.6$ & $37.8 \pm 2.4$ & $136.1 \pm 7.4$ & $1.2 \pm 1.1$ & $12.0 \pm 0.3$ & $3.7 \pm 0.4$ & $38.9 \pm 5.1$ \\
Moll-4 & $4527.3 \pm 683.9$ & $832.2 \pm 231.1$ & $141.6 \pm 9.0$ & $54.2 \pm 3.5$ & $179.9 \pm 10.5$ & $2.9 \pm 2.1$ & $11.7 \pm 0.6$ & $21.4 \pm 1.5$ & $69.5 \pm 4.9$ \\
Moll-5 & $244.8 \pm 57.0$ & $1719.2 \pm 101.4$ & $2392.9 \pm 123.2$ & $8.2 \pm 0.6$ & $93.6 \pm 2.3$ & $0.2 \pm 0.3$ & $34.2 \pm 0.7$ & $14.1 \pm 0.9$ & $48.2 \pm 2.4$ \\
Moll-6 & $53.7 \pm 5.3$ & $977.7 \pm 112.4$ & $12.4 \pm 1.3$ & $5.3 \pm 0.1$ & $138.3 \pm 4.7$ & $1.6 \pm 1.4$ & $8.5 \pm 0.8$ & $5.4 \pm 2.4$ & $33.8 \pm 1.5$ \\
Moll-7 & $39.3 \pm 11.8$ & $579.0 \pm 0.0$ & $12.4 \pm 0.4$ & $21.8 \pm 1.1$ & $166.5 \pm 6.6$ & $2.9 \pm 1.9$ & $6.1 \pm 0.8$ & $6.7 \pm 2.1$ & $97.5 \pm 3.5$ \\
Moll-8 & $614.7 \pm 115.3$ & $953.0 \pm 96.4$ & $95.6 \pm 10.9$ & $23.4 \pm 2.6$ & $228.5 \pm 25.3$ & $2.2 \pm 0.7$ & $6.8 \pm 1.5$ & $9.2 \pm 0.9$ & $80.4 \pm 5.0$ \\
Moll-9 & $247.4 \pm 43.1$ & $839.4 \pm 228.4$ & $405.7 \pm 22.6$ & $9.2 \pm 1.0$ & $383.0 \pm 30.7$ & $2.2 \pm 1.6$ & $17.9 \pm 3.2$ & $10.0 \pm 3.9$ & $55.4 \pm 11.0$ \\
& & & & & & & & & &
\end{tabular}


N.K.S. Singh, M. Sudarshan, A. Chakraborty, Ch.B. Devi, Th.B. Singh, N. R. Singh

Table 3. Comparison of metal concentrations of Pila globosa in Loktak lake with international standards in molluscas/shellfish(dry weight) compiled by the Food and Agricultural Organisation (FAO)

\begin{tabular}{|lcc|}
\hline Element & FAO limit (ppm) dry weight & Pila globosa $(\mathrm{ppm})$ dry weight \\
$\mathrm{Cu}$ & $50-150$ & $5.3-54.2$ \\
$\mathrm{Zn}$ & $200-500$ & $93.6-383.0$ \\
$\mathrm{Se}$ & 1.5 & $0.2-3.2$ \\
& & \\
& & \\
\end{tabular}

Table 4. Karl Pearson's Coefficient of correlation

\begin{tabular}{|c|c|c|c|c|c|c|c|c|c|c|c|c|c|c|c|}
\hline & $\mathrm{Mg}$ & Al & $\mathbf{P}$ & s & $\mathrm{Cl}$ & $\mathrm{K}$ & $\mathrm{Ca}$ & $2 n$ & $\mathrm{Fe}$ & $\mathrm{Cu}$ & $\mathrm{Zn}$ & Se & $\mathrm{Br}$ & $R b$ & $S \mathrm{~s}$ \\
\hline $\mathrm{Mg}$ & 1 & 0.357 & -0.084 & -0.268 & 0.229 & 0.646 & 0.521 & 0.248 & 0.513 & 0.196 & 0.200 & 0.250 & 0.214 & 0.542 & 0.624 \\
\hline Al & & 1 & -0.368 & -0.447 & -0.113 & 0.227 & 0.134 & -0.129 & 0.586 & 0.649 & -0.014 & 0.327 & -0.108 & 0.799 & 0.189 \\
\hline P & & & 1 & 0.665 & 0.804 & 0.406 & -0.715 & 0.799 & 0.322 & -0.235 & -0.233 & -0.598 & 0.827 & -0.064 & -0.539 \\
\hline$s$ & & & & 1 & 0.365 & 0.198 & -0.398 & 0.132 & -0.201 & -0.054 & 0.042 & -0.480 & 0.254 & -0.395 & -0.529 \\
\hline Cl & & & & & 1 & 0.768 & -0.609 & 0.844 & 0.565 & -0.338 & -0.345 & -0.361 & 0.797 & 0.249 & -0.341 \\
\hline $\mathrm{K}$ & & & & & & 1 & -0.118 & 0.549 & 0.667 & -0.108 & -0.008 & -0.142 & 0.550 & 0.533 & -0.008 \\
\hline $\mathrm{Ca}$ & & & & & & & 1 & -0.573 & -0.267 & 0.211 & 0.505 & 0.459 & -0.541 & 0.040 & 0.780 \\
\hline $\mathrm{An}$ & & & & & & & & 1 & 0.668 & -0.319 & -0.258 & -0.415 & 0.941 & 0.306 & -0.265 \\
\hline $\mathrm{Fe}$ & & & & & & & & & 1 & 0.091 & 0.044 & -0.040 & 0.660 & 0.843 & -0.056 \\
\hline $\mathrm{Cu}$ & & & & & & & & & & 1 & -0.081 & 0.102 & -0.215 & 0.321 & 0.203 \\
\hline $\mathrm{Zn}$ & & & & & & & & & & & 1 & 0.213 & -0.083 & 0.041 & 0.169 \\
\hline $\mathrm{Se}$ & & & & & & & & & & & & 1 & -0.442 & 0.084 & 0.431 \\
\hline $\mathrm{Br}$ & & & & & & & & & & & & & 1 & 0.301 & -0.388 \\
\hline $\mathrm{R} \mathrm{k}$ & & & & & & & & & & & & & & 1 & 0.224 \\
\hline $\mathrm{Sr}$ & & & & & & & & & & & & & & & 1 \\
\hline
\end{tabular}


Table 5. Component Score Coefficient Matrix

\begin{tabular}{|c|c|c|c|c|}
\hline & \multicolumn{4}{|c|}{ Component } \\
\hline & 1 & 2 & 3 & 4 \\
\hline $\mathrm{Mg}$ & .005 & .206 & .261 & .091 \\
\hline $\mathrm{Al}$ & -.031 & .191 & -.338 & .111 \\
\hline $\mathrm{P}$ & .163 & -.055 & .039 & .133 \\
\hline S & .082 & -.129 & .065 & .552 \\
\hline $\mathrm{Cl}$ & .162 & .040 & .077 & -.096 \\
\hline K & .106 & .142 & .161 & .142 \\
\hline $\mathrm{Ca}$ & -.133 & .086 & .276 & .143 \\
\hline $\mathrm{Mn}$ & .159 & .053 & .074 & -.206 \\
\hline $\mathrm{Fe}$ & .098 & .190 & -.082 & -.018 \\
\hline $\mathrm{Cu}$ & -.053 & .089 & -.334 & .444 \\
\hline $\mathrm{Zn}$ & -.051 & .036 & .295 & .414 \\
\hline $\mathrm{Se}$ & -.102 & .084 & .050 & -.225 \\
\hline $\mathrm{Br}$ & .159 & .047 & .066 & -.005 \\
\hline $\mathrm{Sr}$ & -.098 & .127 & .231 & -.120 \\
\hline $\mathrm{Rb}$ & .034 & .221 & -.154 & .021 \\
\hline
\end{tabular}

${ }^{*}$ Extraction Method: Principal Component Analysis. 